\title{
Pulmonary infections due to brucellosis in childhood
}

Gülsüm İclal

BAYHAN $^{1}($ ID)

Abdussamet BATUR ${ }^{2}(\| \mathrm{D})$ Ibrahim $\mathrm{ECE}^{3}(\mathrm{ID})$
Cite this article as: Bayhan Gi, Batur A, Ece i. Pulmonary infections due to brucellosis in childhood. Tuberk Toraks 2020;68(1):43-47.

\section{Yazışma Adresi (Address for Correspondence)}

\section{Dr. Gülsüm İclal BAYHAN}

Yüzüncü Yıl Üniversitesi Tıp Fakültesi,

Dursun Odabaş Tıp Merkezi,

Çocuk Infeksiyon Hastalıkları Bilim Dalı,

VAN - TÜRKIYE

e-mail: gibayhan@gmail.com

CCopyright 2020 by Tuberculosis and Thorax.

Available on-line at www.tuberktoraks.org.com
${ }^{1}$ Division of Pediatric Infectious Diseases, Dursun Odabas Medical Center, Faculty of Medicine, Yuzuncu Yil University, Van, Turkey

${ }^{1}$ Yüzüncü Yıl Üniversitesi Tıp Fakültesi, Dursun Odabaş Tıp Merkezi, Çocuk infeksiyon Hastalıkları Bilim Dalı, Van, Türkiye

${ }^{2}$ Division of Pediatric Radiology, Dursun Odabas Medical Center, Faculty of Medicine, Yuzuncu Yil University, Van, Turkey

2 Yüzüncü Yıl Üniversitesi Tıp Fakültesi, Dursun Odabaş Tıp Merkezi, Çocuk Radyoloji Bilim Dalı, Van, Türkiye

${ }^{3}$ Division of Pediatric Cardiology, Dursun Odabas Medical Center, Faculty of Medicine, Yuzuncu Yil University, Van, Turkey

${ }^{3}$ Yüzüncü Yıl Üniversitesi Tıp Fakültesi, Dursun Odabaş Tıp Merkezi, Çocuk Kardiyoloji Bilim Dalı, Van, Türkiye

\begin{abstract}
Pulmonary infections due to brucellosis in childhood

Introduction: Brucellosis is widely distributed zoonotic infection. Brucellosis is a multisystemic disease but pulmonary infection due to brucellosis is very rarely reported.
\end{abstract}

Materials and Methods: We retrospectively evaluated our pediatric brucellosis cases between February 2014 and December 2015. The brucellosis patients with and without pulmonary infection were compared with each other.

Results: We detected pulmonary infection in 18 of the 98 brucellosis patients. There was no statistical significant difference between the brucellosis patients with and without a pulmonary infection as regards age, gender, and animal husbandry history. The laboratory findings including the Brucella Coombs agglutination titers were also similar. The most common chest X-ray findings were interstitial infiltration and hilar lymphadenopathy. All of our cases with pulmonary infection recovered with the usual anti-brucella treatment.

Conclusion: Brucellosis may cause a pulmonary infection more often than thought. The prognosis of respiratory brucellosis is good and the classic treatment regimen is appropriate.

Key words: Brucellosis; Brucella melitensis; lung; respiratory infection; child 
ÖZ

\section{Çocukluk çağında bruselloza bağıı akciğer infeksiyonları}

Giriş: Bruselloz tüm dünyada en yaygın görülen zoonotik infeksiyon hastalığıdır. Bruselloz multisistemik bir hastalıktır ancak bruselloza bağlı akciğer infeksiyonu nadiren bildirilmiştir.

Materyal ve Metod: Pediatrik bruselloz olgularımızı geriye dönük olarak araştırdık ve respiratuvar komplikasyonu olan bruselloz hastalarımızı inceledik. Respiratuvar komplikasyonu olan ve olmayan hastalarımızı birbirleriyle kıyasladık.

Bulgular: Doksan sekiz brusellozlu olgunun 18'inde akciğer infeksiyonu vardı. Akciğer infeksiyonu olan ve olmayan hastalar arasında yaş, cinsiyet ve hayvancılık yapma öyküsü yönünden istatistiksel fark yoktu. Laboratuvar bulguları ve Brucella Coombs aglütinasyon titreleri benzerdi. En sık akciğer bulgusu interstisyel infiltrasyon ve hilar lenfadenopatiydi. Akciğer infeksiyonu olan tüm hastalar klasik bruselloz tedavisi ile düzeldi.

Sonuç: Bruselloz akciğer infeksiyonuna düşünüldügünden daha sık yol açıyor olabilir. Respiratuvar brusellozun prognozu iyidir ve tedavisinde klasik tedavi rejimi uygundur.

Anahtar kelimeler: Bruselloz; Brucella melitensis; akciğer; solunum yolu infeksiyonları; çocuk

\section{INTRODUCTION}

Brucellosis is a widespread zoonosis and endemic in the Mediterranean countries, Middle East, Central Asia, India, Mexico and Central and South America (1). Brucellosis is still an important public health problem in Turkey and is highly endemic in Eastern and Southeast Anatolia regions as brucellosis in animals has not been controlled (2). While the most common clinical presentation is with osteoarticular problems, brucellosis is a multisystemic disease that can affect every organ and system of the human body (1-4). It is also known that brucellosis can very rarely cause respiratory complications (5). These can often be missed because the their rarity and the clinician's focus on other system involvement. We evaluated the respiratory complications of our pediatric brucellosis cases from the Van province of Eastern Turkey where brucellosis is highly endemic in this study.

\section{MATERIALS and METHODS}

The patients diagnosed with brucellosis between February 2014 and December 2015 were retrospectively found from the medical database of Dursun Odabas Medical Center of Yuzuncu Yil University. The diagnosis of brucellosis was made with a Coombs (agglutinin) test titer of $\geq 1 / 160$, and/or isolation of Brucella species from the blood in a patient with clinical symptoms and signs compatible with brucellosis. Respiratory infection was defined as the presence of abnormalities on chest $\mathrm{X}$-ray. The chest $\mathrm{X}$-rays were evaluated by a radiologist. The brucellosis patients with and without pulmonary infection were compared with each other as regards age, gender, history of animal husbandry, laboratory findings, and the presence of other system complications. The treatments were recorded. All patients had been followed up for 6-12 months after treatment cessation.

Statistical analyses were made by using SPSS 15.0. The chi-square test was used for nominal variables. Analysis of ordinal variables conforming to a normal distribution was conducted with the two independent samples T-test while ordinal variables without a normal distribution were analyzed with the MannWhitney $U$ test.

\section{RESULTS}

A total of 98 patients with brucellosis were identified and $18(18.4 \%)$ patients had a pulmonary infection. The comparison of the brucellosis patients with and without a pulmonary infection as regards their demographic characteristics and laboratory findings is shown in Table 1. A blood culture was not obtained from every patient but 1 of the 3 patients with a pulmonary infection and 9 of the 16 patients without a pulmonary infection were positive for brucellosis on blood culture among those with a blood culture result $(p=0.58)$.

Osteoarticular brucellosis was also present in $89 \%$ of the patients with a pulmonary infection, and hepatitis and cytopenia were the other detected complications. None of the patients with a pulmonary infection had meningoencephalitis. There was no difference between the brucellosis complication frequency between the two groups (Table 2).

Chest X-ray findings are presented in Table 3. None of the patients underwent thorax CT. All patients $>8$ years old were treated with doxycycline and rifampin while those $<8$ years old were treated with trimethoprim-sulfamethoxazole and rifampin. Gentamicin 
Table 1. Comparison of the demographic characteristics and laboratory values of patients with and without respiratory complications

\begin{tabular}{|c|c|c|c|}
\hline & $\begin{array}{l}\text { Brucellosis patients with } \\
\text { respiratory complications } \\
(n=18), n(\%)\end{array}$ & $\begin{array}{l}\text { Brucellosis patients without } \\
\text { respiratory complications } \\
(n=80), n(\%)\end{array}$ & $\mathbf{p}$ \\
\hline Age (months) $($ mean $\pm \mathrm{SD})$ & $9.7 \pm 4.2$ & $10.5 \pm 3.5$ & 0.40 \\
\hline Gender (male/female) & $14 / 4$ & $55 / 25$ & 0.57 \\
\hline Animal husbandry, n (\%) & $13(86.7)$ & $42(80.8)$ & 0.72 \\
\hline Brucella Coombs agglutination titer & $1 / 640$ & $1 / 640$ & 0.67 \\
\hline $\mathrm{CRP}(\mathrm{mg} / \mathrm{L})$ & 6 & 3 & 0.60 \\
\hline ESR $[\mathrm{mm} /$ hour $($ mean $\pm \mathrm{SD})]$ & $27.6 \pm 14.1$ & $24.9 \pm 15.5$ & 0.57 \\
\hline $\mathrm{Hgb}[\mathrm{g} / \mathrm{dL}($ mean $\pm \mathrm{SD})]$ & $11.8 \pm 1.1$ & $12.1 \pm 1.3$ & 0.42 \\
\hline $\mathrm{PLT} \times 10^{3} / \mu \mathrm{L}($ mean $\pm \mathrm{SD})$ & $287000 \pm 108541$ & $281000 \pm 112071$ & 0.84 \\
\hline $\mathrm{WBC} / \mu \mathrm{L}($ mean $\pm \mathrm{SD})$ & $6552 \pm 2427$ & $7556 \pm 3408$ & 0.25 \\
\hline
\end{tabular}

Table 2. Other system complications of the patients with and without respiratory complications

\begin{tabular}{|lccc|}
\hline & $\begin{array}{c}\text { Brucellosis patients with } \\
\text { respiratory complications } \\
(\mathbf{n = 1 8}) \mathbf{n}(\%)\end{array}$ & $\begin{array}{c}\text { Brucellosis patients without } \\
\text { respiratory complications } \\
(\mathbf{n = 8 0}), \mathbf{n}(\%)\end{array}$ & $\mathbf{p}$ \\
\hline Arthralgia & $11(77.8)$ & $56(70)$ & 0.57 \\
Sacroileitis & $2(11.2)$ & $3(3.8)$ & 0.22 \\
Arthritis & $0(0)$ & $1(1.2)$ & 1 \\
Osteomyelitis & $0(0)$ & $3(3.8)$ & 1 \\
Meningoencephalitis & $0(0)$ & $2(2.5)$ & 1 \\
Hepatitis & $3(17.6)$ & $17(21.8)$ & 1 \\
Cytopenia & $2(11.1)$ & $8(10.1)$ & 1 \\
\hline
\end{tabular}

Table 3. Chest $X$-ray findings of the patients with respiratory complications

$\begin{array}{ll}\text { Interstitial infiltration } & 7(38.8 \%) \\ \text { Parenchymal micronodules } & 1(5.5 \%) \\ \text { Consolidation } & 5(27.7 \%) \\ \text { Hilar lypmhadenopathy } & 8(44.4 \%)\end{array}$

was added to the treatment combination in patients who had meningoencephalitis or sacroileitis. No adverse reaction was observed

\section{DISCUSSION}

Brucellosis is the most common zoonotic disease globally. Respiratory involvement is quite rare but a well-described complication (6). The incidence of respiratory involvement has been reported as 1-10\% (6-8). We found a higher incidence than reported in the literature. The reason may be that a chest X-ray was taken when any patient reported a cough even if the respiratory examination was normal. Serologic and microbiologic investigations for other etiological agents of pulmonary infection had not been conducted as the patients had already been diagnosed with 
brucellosis and recovered with anti-brucella treatment. It is possible that other etiologic agents such as Mycoplasma pneumoniae were present in some of our patients and they too recovered with doxycycline.

Pappas et al. reported that 31 of their 450 brucellosis cases had a respiratory infection. An interstitial pattern and lobar pneumonia were reported as the most common findings on chest X-ray $(40.5 \%$ and $32.4 \%$, respectively) (6). Other findings of pulmonary brucellosis included hilar and paratracheal lymphadenopathy, pleural effusion, honeycomb pattern, lobar pneumonia, and parenchymal nodules $(6,7,9)$. The radiologic findings of our patients were similar to the previously reported cases.

The main transmission route of brucellosis is the consumption of infected unpasteurized milk and milk products, contact with infected animal parts, and inhalation of dust contaminated with Brucella spp. (4). The question comes to mind as to whether pulmonary brucellosis develops following inhalation of the bacteria. Brucellosis development due to aerosolisation is well defined in laboratory workers as the disease has developed in the absence of any other risk factor in those who have manipulated the organism outside a biological safety cabinet or worked with unsafe laboratory practices. However, none of these laboratory workers developed pulmonary brucellosis (10). Another study has reported that the most common risk factors in patients who suffered from brucellosis with pulmonary involvement were consumption of unpasteurized dairy products $(61.9 \%)$, other risk factors related to raising livestock $(17.3 \%)$, and being a veterinarian or veterinary staff member (1.5\%) (7). Mense et al. have studied the effect of Brucella melitensis on tissues following intranasal inoculation in a mouse model (11). They found measurable splenic and hepatic changes without histologic changes in the lung in these mice. There were no gross or microscopic findings of an inflammatory response in the respiratory tract, both in the acute postinoculation period and 4 weeks later, although it was possible to grow B. melitensis in the bacterial culture of lung specimens. They hypothesized that the lack of an inflammatory response despite the presence of bacteria in the lungs may be the result of intracellular localization of the Brucellae spp. in alveolar macrophages or dendritic cells immediately following inoculation. B. melitensis could avoid the immune surveillance system in this way with the host failing to induce an inflammatory response, thus allowing intracellular proliferation and dissemination within the host (11). These findings indicate that inhalation of the bacillus may not be directly related to pulmonary involvement. The respiratory involvement of brucellosis may actually be developing via hematogenous distribution of the bacillus.

The complication rate increases if brucellosis is left untreated for a long time (5). The Brucella agglutination titer increases with prolongation of the disorder and high titers are associated with untreated prolonged disease. We wonder whether the respiratory involvement is related to duration of disease. We found that the Brucella agglutination titer was similar between the brucellosis groups with and without pulmonary findings and we believe that the duration of illness may also be similar between two groups. The classic brucellosis treatment was also appropriate for respiratory involvement (6-8). All of our cases recovered completely with the usual anti-brucella treatment.

A limitation of this study is that we evaluated the brucellosis cases retrospectively. None of the patients were specifically evaluated about other etiological agents of lung infections. However, all our patients recovered with anti-brucella treatment, and there was no recurrence during the 6-12 months of follow-up.

In conclusion, brucellosis may cause a pulmonary infection more often than is currently thought. There seems to be no relationship between the development of lung infection and transmission by inhalation. The prognosis of respiratory brucellosis is good and the classic treatment regimen is suitable.

\section{CONFLICT of INTEREST}

There is no conflict of interest related to this study.

\section{AUTHORSHIP CONTRIBUTIONS}

Concept/Design: GiB, iE, AB

Analysis/Interpretation: $\mathrm{GiB}, \mathrm{AB}$

Data Acquisition: $G \mathrm{~B} B, \mathrm{AB}$, IE

Writting: GiB, AB

Critical Revision: GiB, $A B$

Final Approval: GiB, IE 


\section{REFERENCES}

1. Seleem MN, Boyle SM, Sriranganathan N. Brucellosis: a re-emerging zoonosis. Vet Microbiol 2010;140:392-8.

2. https://hsgm.saglik.gov.tr/depo/birimler/zoonotik-vektorel-hastaliklar-db/zoonotik-hastaliklar/9-Bruselloz/3istatistik/Web_Bruselloz_haritasi.pdf (access date 30 October 2019

3. Solera J, Solis Garcia Del Pozo J. Treatment of pulmonary brucellosis: a systematic review. Expert Rev Anti Infect Ther 2017; 15:33-42.

4. Pappas G, Akritidis N, Bosilkovski M, Tsianos E. Brucellosis. N Engl I Med 2005;352:2325-36.

5. Al Dahouk S, Nöckler K, Hensel A, Tomaso H, Scholz HC, Hagen RM, et al. Human brucellosis in a nonendemic country: a report from Germany, 2002 and 2003. Eur J Clin Microbiol Infect Dis 2005;24:450-6.

6. Pappas G, Bosilkovski M, Akritidis N, Mastora M, Krteva L, Tsianos E. Brucellosis and the respiratory system. Clin Infect Dis 2003;37:95-9.
7. Erdem H, Inan A, Elaldi N, Tekin R, Gulsun S, Ataman Hatipoglu C, et al.; Brucellosis Study Group. Respiratory system involvement in brucellosis: the results of the Kardelen study. Chest 2014;145:87-94.

8. Hatipoglu CA, Bilgin G, Tulek N, Kosar U. Pulmonary involvement in brucellosis. J Infect 2005;51:116-9.

9. Aliaga L, Cobo F, Cueto A, Rosa-Fraile M. Pulmonary infection due to Brucella melitensis. Int I Infect Dis 2001;5:2323.

10. Traxler RM, Lehman MW, Bosserman EA, Guerra MA, Smith TL. A literature review of laboratory-acquired brucellosis. J Clin Microbiol 2013;51:3055-62.

11. Mense $M G$, Van De Verg $L L$, Bhattacharjee AK, Garrett $J$, Hart JA, Lindler LE, et al. Bacteriologic and histologic features in mice after intranasal inoculation of Brucella melitensis. Am J Vet Res 2001;62:398-405. 